\title{
Transpiration and biomass production of the bioenergy crop Giant Knotweed Igniscum under various supplies of water and nutrients
}

\author{
Dario Mantovani ${ }^{1}$, Maik Veste $^{2 *}$, Stella Gypser ${ }^{1}$, Christian Halke $^{1}$, Laurie Koning ${ }^{1}$, Dirk Freese ${ }^{1}$, \\ Stefan Lebzien ${ }^{3}$ \\ ${ }^{1}$ Brandenburg University of Technology Cottbus-Senftenberg, Chair of Soil Protection and Recultivation, Konrad-Wachsmann-Allee 6, \\ D-03046 Cottbus, Germany. \\ ${ }^{2}$ CEBra - Centre for Energy Technology Brandenburg e.V., Friedlieb-Runge-Strasse 3, D-03046 Cottbus, Germany. \\ ${ }^{3}$ ENAGRA Biomasse GmbH, Auf der Grub 1, D-54472 Monzelfeld, Germany. \\ ${ }^{*}$ Corresponding author. Tel.: +49 355 696602. E-mail: maik.veste@me.com
}

\begin{abstract}
Soil water availability, nutrient supply and climatic conditions are key factors for plant production. For a sustainable integration of bioenergy plants into agricultural systems, detailed studies on their water uses and growth performances are needed. The new bioenergy plant Igniscum Candy is a cultivar of the Sakhalin Knotweed (Fallopia sachalinensis), which is characterized by a high annual biomass production. For the determination of transpiration-yield relations at the whole plant level we used wicked lysimeters at multiple irrigation levels associated with the soil water availability $(25,35,70,100 \%)$ and nitrogen fertilization $\left(0,50,100,150 \mathrm{~kg} \mathrm{~N}^{-1}\right)$. Leaf transpiration and net photosynthesis were determined with a portable minicuvette system. The maximum mean transpiration rate was 10.6 mmol m $\mathrm{m}^{-2} \mathrm{~s}^{-1}$ for well-watered plants, while the mean net photosynthesis was $9.1 \mu \mathrm{mol} \mathrm{m} \mathrm{m}^{-1}$. The cumulative transpiration of the plants during the growing seasons varied between 491 (drought stressed) and 1411 (well-watered) per plant. The calculated transpiration coefficient for Fallopia over all of the treatments applied was $485.61 \mathrm{~kg}^{-1}$. The transpiration-yield relation of Igniscum is comparable to rye and barley. Its growth performance making Fallopia a potentially good second generation bioenergy crop.
\end{abstract}

Keywords: Water use efficiency; Transpiration coefficient; Photosynthesis; Nitrogen; Ecophysiology; Lysimeter; Fallopia.

\section{INTRODUCTION}

Understanding the water consumption of crops under various soil water availabilities is critical for sustainable and economically feasible agricultural production under varying climatic conditions. Yield-transpiration relationships measured in a microcosm by using lysimeters under various water application regimes and nutrient content as well as soil conditions allows for an estimation of potential water requirements of crops under varying climate conditions (BenGal et al., 2003; Hanks, 1974). This information is practical for use in the field. Experimental evidence that supports linear relationships between yield and potential evapotranspiration has been reported for various forage and crop biomass products and can be used for the prediction of biomass production (Ben-Gal and Shani, 2002a; Hanks and Rasmussen, 1982; Shani et al., 2007). The increased demand for bioenergy crops for biomass production and biogas (Weiland, 2010) will affect land use management systems (Gerbens-Leenes et al., 2009) as well as local hydrological cycles (Phong et al., 2011). Therefore, before the introduction of a new species as a second generation crop for bioenergy production and for raw materials, an analysis of its water consumption is mandatory for optimal agricultural management and limited soil water availability have negative effects on crop productivity (Ings et al., 2003). Second generation bioenergy crops avoid competition with food and feed production, reduce the environmental impacts of fertilizers and herbicides, and enhance biodiversity in the landscape (Gomez et al., 2008; Havlík et al., 2011; Naik et al., 2009). Especially herbaceous perennials have great potentials to fulfill these criteria and various new species for bioenergy production have been tested, e.g., Miscanthus giganteus, Silphium perfoliatum, Sida hermaphrodita and Fallopia x bohemica (Borkowska and Molas, 2012; Franzing et al., 2014; Lewandowski et al., 2000; Pude and Franken, 2001, Lewandowski and Heinz, 2003; Strašil and Kára, 2010). The Giant Knotweed, or Sakhalin Knotweed (Fallopia sachalinensis), grows natively on the Russian island of Sakhalin, in Japan and on the Korean peninsula. It is characterized by high annual biomass production (Lebzien et al., 2012; Vetter et al., 2009). The plant can reach heights of up to 3-4 m. The new cultivars Igniscum Candy and Igniscum Basic were selected and cultured from the wild form as new bioenergy crops (Veste et al., 2011) and can be effectively used in biogas plants and for combustion, respectively. First results from lab investigations and experiments in biogas plants show that with Igniscum Candy's two possible harvests during the year and ability to be a good substitute for maize as a substrate in biogas power plants, it is a promising bioenergy crop (Seppälä et al., 2013). However, until now detailed information on its water consumption and how that affects its biomass production is still missing. The objective of this experiment was to investigate the growth, yield and transpiration responses of Igniscum Candy to various water and nitrogen supplies. The determination of the yield-transpiration relations under different under the influence of different water and nitrogen regimes will give important basic information on the growth performance under different soil water availability compared to other crops. Furthermore, the water use efficiency was investigated on the whole plant level and on the level to understand the influence of drought stress on the ecophysiological plasticity to water constrains. 


\section{MATERIAL AND METHODS \\ Plant material and cultivation}

For the experiment we used Igniscum Candy, which is a selected cultivar of Fallopia $\mathrm{cf}$. sachalinensis. One-year-old saplings of the plants obtained from Conpower Rohstoffe $\mathrm{GmbH}$, Oldenburg were transplanted from small seedling pots to 71 volume plastic pots and stored in the glasshouse at the Brandenburg University of Technology in Cottbus. The plants were maintained at temperatures above $10^{\circ} \mathrm{C}$ under well-watered conditions. After 60 days the saplings were cut back to facilitate homogeneous re-sprouting. Each plant was fertilized with $200 \mathrm{ml}$ of Hoagland standard solution, $0.78 \mathrm{~g}$ calcium ammonium nitrate $\left(\mathrm{NH}_{4} \mathrm{NO}_{3}\right)$ and $0.63 \mathrm{~g}$ superphosphate $\left(\mathrm{KH}_{2} \mathrm{PO}_{4}\right)$, and then watered well. After 55 days the plants were transplanted into lysimeters where they were fertilized with $1045 \mathrm{ml}$ of Hoagland standard solution, $2.58 \mathrm{~g}$ calcium ammonium nitrate $\left(\mathrm{NH}_{4} \mathrm{NO}_{3}\right)$ and $1.59 \mathrm{~g}$ potassium superphosphate $\left(\mathrm{KH}_{2} \mathrm{PO}_{4}\right)$, and again watered well to allow for their establishment until the start of the experiment (June $26^{\text {st }}, 2011$ ). After the first vegetation period the shoots were cut back and the lysimeters were stored in an area protected from frost where they could safely overwinter.

\section{Experimental design}

The experiments to determine the yield-transpiration relation were conducted by maintaining the plants for two vegetation periods under pre-defined water availability regimes and fertilization rates. All the treatments were tested in three replicates for a total of 21 lysimeters. The lysimeters where filled with sandy loam, at bulk density $1.3 \mathrm{~g} \mathrm{~cm}^{-3}$. The soil, relatively low in organic carbon $(1.3 \%)$ and total nitrogen $(0.08 \%)$, presented the oxalate-extractable $\mathrm{Al}, \mathrm{Fe}$, and $\mathrm{Mn}$ content values of $0.65,1.53$, and $0.08 \mathrm{mg} \mathrm{g}^{-1}$, respectively.

There were three water treatments for the 2011 experiment, namely, SWA 35, SWA 70 and SWA 100, associated with the relative soil water availability (SWA) set at 35,70 , and $100 \%$ of the lysimeter field capacity, respectively (for details see Mantovani et al., 2013). Since Fallopia showed a high tolerance to drought stress in the first year of the experiment (2011), in the second year of investigation (2012) we added a supplemental treatment with the SWA set to $25 \%$ (SWA 25) close to the wilting point. The water treatments were submitted to the same fertilization rate correspondent to a $50 \mathrm{~kg} \mathrm{~N}^{-1}$ applied at the start of the growing season in both years of investigations. In a second experiment four nitrogen treatments were applied as calcium ammonium nitrate $\left(\mathrm{NH}_{4} \mathrm{NO}_{3}\right)$ in the form of pellets, which corresponded to $0,50,100$, and $150 \mathrm{~kg} \mathrm{~N} \mathrm{ha}^{-1}$ (named $\mathrm{N}$ $0, \mathrm{~N} 50, \mathrm{~N} 100, \mathrm{~N} 150$ ), respectively. All the $\mathrm{N}$ treatments were maintained under well-watered conditions (SWA 100) throughout both years.

\section{Water balance}

The water balances were determined in free-standing wicked lysimeters placed under a light-transmissive roof at the glasshouse of the Brandenburg University of Technology in Cottbus-Senftenberg, Germany. Twenty-one wicked lysimeters, each with a volume of 100 1, were filled with homogenized sandy loam. The extension drainage dimension and the mineral wool density were selected in relation to soil type, column dimension and the hydraulic property of the specific wick material (Mantovani et al., 2011), following the theoretical consideration formulated by Ben-Gal and Shani (2002b) and
Lazarovitch et al. (2006). A $5 \mathrm{~cm}$ mineral wool layer was befitted between the soil bottom layer and the lysimeter base. The base connected to the drainage extension. Water was supplied from an automatic drip irrigation system controlled by a GP-1 data logger (Delta-T Devices, Cambridge, UK) when the soil moisture reached values lower than the pre-defined lower limit. To control the irrigation amount and frequency, the soil moisture was measured at a depth of $20 \mathrm{~cm}$ with a FDR probe (SM-200, Frequency Domain Reflectometry, Soil Moisture Sensor Delta-T Devices, Cambridge, UK). Variations in water storage were determined through calculations of the weekly water budget based on weekly measurements of the soil moisture at four depths $(10,20,30$, and $40 \mathrm{~cm})$ with a portable FDR profile probe (PR2/4w-02, Delta-T Devices, Cambridge, UK). Plant transpiration was calculated from the experimental water balance following equation:

$\mathrm{T}=\mathrm{I}-(\mathrm{E}+\mathrm{D}+\Delta \mathrm{S})$

where $\mathrm{T}$ is the plant transpiration, $\mathrm{I}=$ irrigation, $\mathrm{E}=$ evaporation, $\mathrm{D}=$ drainage and $\Delta \mathrm{S}=$ soil water storage changes. To avoid evaporation, each soil surface was covered with a garden fleece, and thus E can be set to 0 .

\section{Microclimate}

Air temperature and relative air humidity were recorded directly under the roof on an hourly basis and stored in a GP-1 data logger. Daily mean values of air temperature and relative humidity were calculated for the daytime from 8:00 a.m. to 5 p.m. local time (CET). The data set obtained was used to compute the daily mean of the vapor pressure deficit (VPD). The mean of the daily temperatures recorded during the vegetation period 2011 was $23.9^{\circ} \mathrm{C}$, with the daily mean temperature above $30^{\circ} \mathrm{C}$ on 13 days and a peak of $33.5^{\circ} \mathrm{C}$ occurring at the end of August (Fig. 1a). However, the atmospheric evaporative demand was higher in June, with a mean monthly VPD of $20 \mathrm{hPa}$ (Fig. 1b). The VPD decreased in July, August and September with monthly means of 13.2, 13.9 and $12.9 \mathrm{hPa}$, respectively. The vegetation period 2012 was warmer compared to 2011 , with a daily mean temperature of $25^{\circ} \mathrm{C}$ and 17 days were above $30^{\circ} \mathrm{C}$. A maximum air temperature of $39.3^{\circ} \mathrm{C}$ occurred in the middle of August (Fig. 1b). The year 2012 was characterized by a relatively high fluctuation of the monthly VPD, with the lowest values in June $(12.5 \mathrm{hPa})$ and September $(13.2 \mathrm{hPa})$ and a peak in August $(22.7 \mathrm{hPa})$.

\section{Leaf gas exchange}

The gas exchange of fully expanded leaves was measured with a CMS 400 minicuvette system (Heinz Walz GmbH, Effeltrich, Germany) (Midgley et al., 1997). The gas exchange measurements were carried out under ambient $\mathrm{CO}_{2}$ concentrations (Veste and Herppich, 1995). $\mathrm{H}_{2} \mathrm{O}$ and $\mathrm{CO}_{2}$ fluxes were determined with an infra-red gas analyzer (BINOS 100$4 \mathrm{P}$, Rosemount, Hanau, Germany) and all fluxes were expressed on the projected leaf area. Transpiration, net $\mathrm{CO}_{2}$ exchange and leaf conductance for water vapor were calculated using the standard software DIAGAS 2.0 (Heinz Walz GmbH, Effeltrich, Germany). For the determination of the leaf area, the leaves were scanned and the surface estimated by using a digital image processing technique (GNU Image Manipulation Program 2.6, Berkeley, California, and UTHSCSA ImageTool, San Antonio, Texas). The illumination was set to a constant $1100 \mu \mathrm{mol} \mathrm{m}^{-2} \mathrm{~s}^{-1}$ 

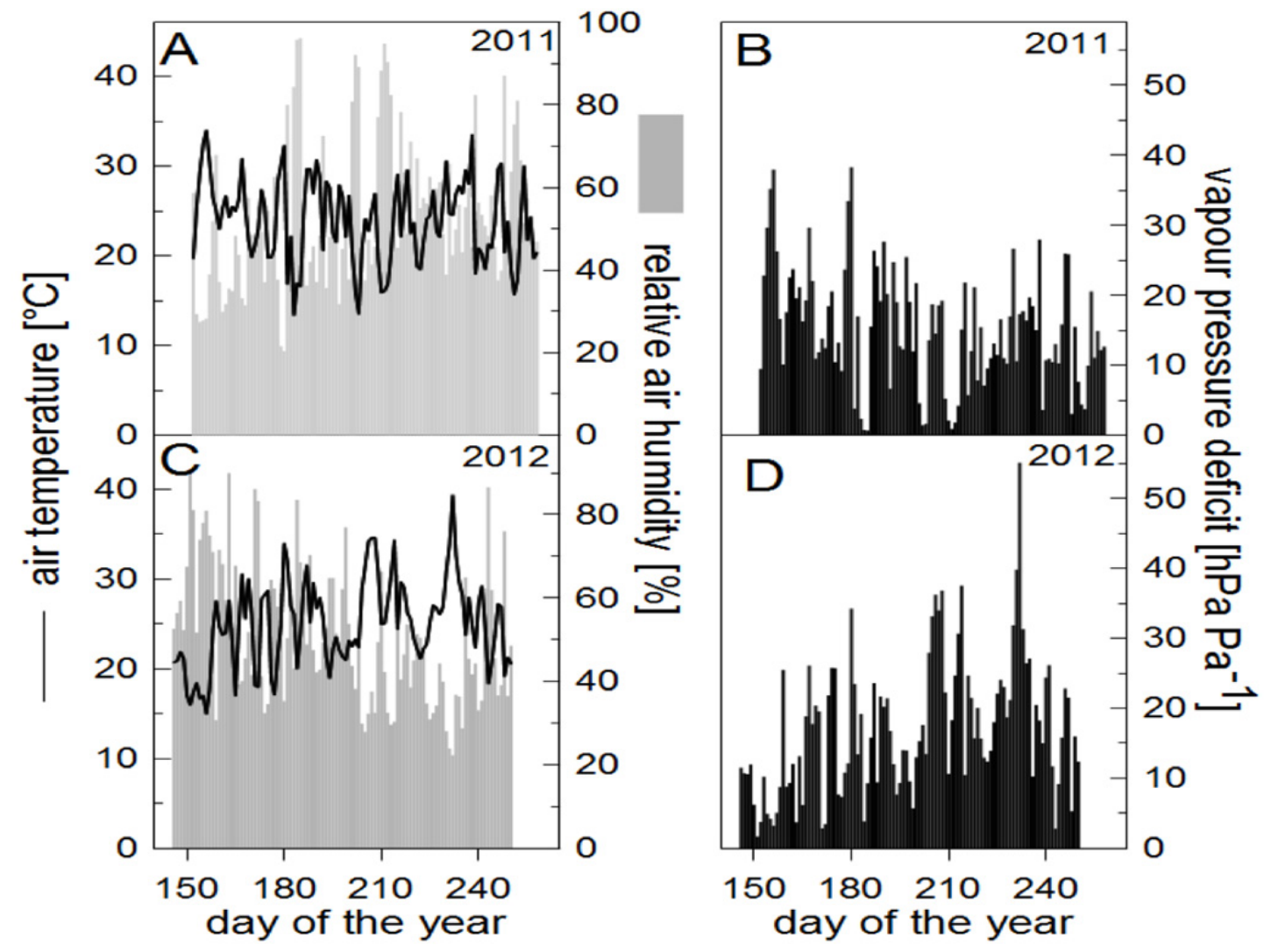

Fig. 1. Mean daily air temperature and mean relative air humidity during the experiments from (A) June $1^{\text {st }}$ to September $16^{\text {th }}, 2011$ (C) from May $26^{\text {th }}$ to September $8^{\text {th }}, 2012$ and mean vapor pressure deficit during the experiments from (B) June $1^{\text {st }}$ to September $16^{\text {th }}, 2011$ (D) from May $26^{\text {th }}$ to September $8^{\text {th }}, 2012$.

with an external halogen lamp to ensure light-saturation during photosynthesis. Air temperature and air humidity (measured as air to leaf water vapor pressure deficit, ALVPD) in the cuvette corresponded closely to the actual ambient conditions and were kept constant during the measurements. We selected three different temperature and humidity conditions: I) $T_{\text {cuv }}=20^{\circ} \mathrm{C}, \mathrm{rH}=$ $74 \%$, and ALVPD $=8.9 \mathrm{mPa} \mathrm{Pa}{ }^{-1}$, II) $T_{\text {cuv }}=25^{\circ} \mathrm{C}, \mathrm{rH}=53 \%$ and ALVPD $=14.9 \mathrm{mPa} \mathrm{Pa}{ }^{-1}$, and III) $T_{\text {cuv }}=30^{\circ} \mathrm{C}, \mathrm{rH}=51 \%$, and $A L V P D=20.8 \mathrm{mPa} \mathrm{Pa}^{-1}$, representing typical summer days.

\section{Biomass determination}

Aboveground biomass was harvested in the first year of the experiment on September $16^{\text {th }}, 2011$ and on September $8^{\text {th }}, 2012$ in the second year. The fresh weight of leaves and stems were weighed separately. Plant material was oven-dried at $65^{\circ} \mathrm{C}$ until it reached a constant weight for the determination of dry weight. Yield-transpiration relations were obtained from linear regression analysis in three different ways: (I) Since the biomass production of the plant is for biogas production, which implies the use of fresh material, the yield water use efficiency (YWUE) was calculated according to the relation between the total aboveground fresh biomass and the cumulative transpiration; (II) Water use efficiency (WUE) was calculated according to the ratio between the total aboveground dry biomass evaluated at the harvest and the cumulative transpiration; (III) The transpiration coefficient (TC) was calculated according to the relation between the cumulative transpiration and the total dry matter of aboveground biomass.

\section{Statistical analysis}

The statistical analysis was performed using IBM SPSS software, version 21 (SPSS Inc., Chicago, IL, USA) and Microsoft-Excel software. A non-parametric analysis, the MannWhitney test (significant at level of 0.05), was performed to compare (a) cumulative transpiration, (b) yield, (c) total aboveground dry biomass, (d) YWUE (e) WUE and (f) TC at the whole plant level. Furthermore, a non-parametric Spearman's rho analysis (significant level of $0.01^{* *}$ and $0.05^{*}$ ) and linear regression analysis were used to correlate (a) the total fresh biomass and total dry biomass with the cumulative transpiration, and (b) the total fresh biomass and total dry biomass with the fertilization amount. At the leaf level we used the MannWhitney test (significant at level of 0.05 ) to compare the (a) transpiration rate and (b) the net photosynthesis.

\section{RESULTS AND DISCUSSION}

For both water experiments in 2011 and 2012, the soil water availability reduction lead to a water use decrease (Fig. 2a). In the 2011 water experiment, the SWA 100 water use was significantly different compared to all the other treatments, being $34 \%$ and $68 \%$ higher compared to the SWA 70 and SWA 35 , respectively. Significant differences in terms of cumulative transpiration were found between the water treatments during the 2012 experiment as well. The SWA 100 and SWA 70 water treatments, with water uses of 141 and 1291 , respectively, were comparable but significantly different from SWA 35 (109 1) and SWA 25 (69 1) (Fig. 2a). For the $\mathrm{N}$ experiments in 2011 there 


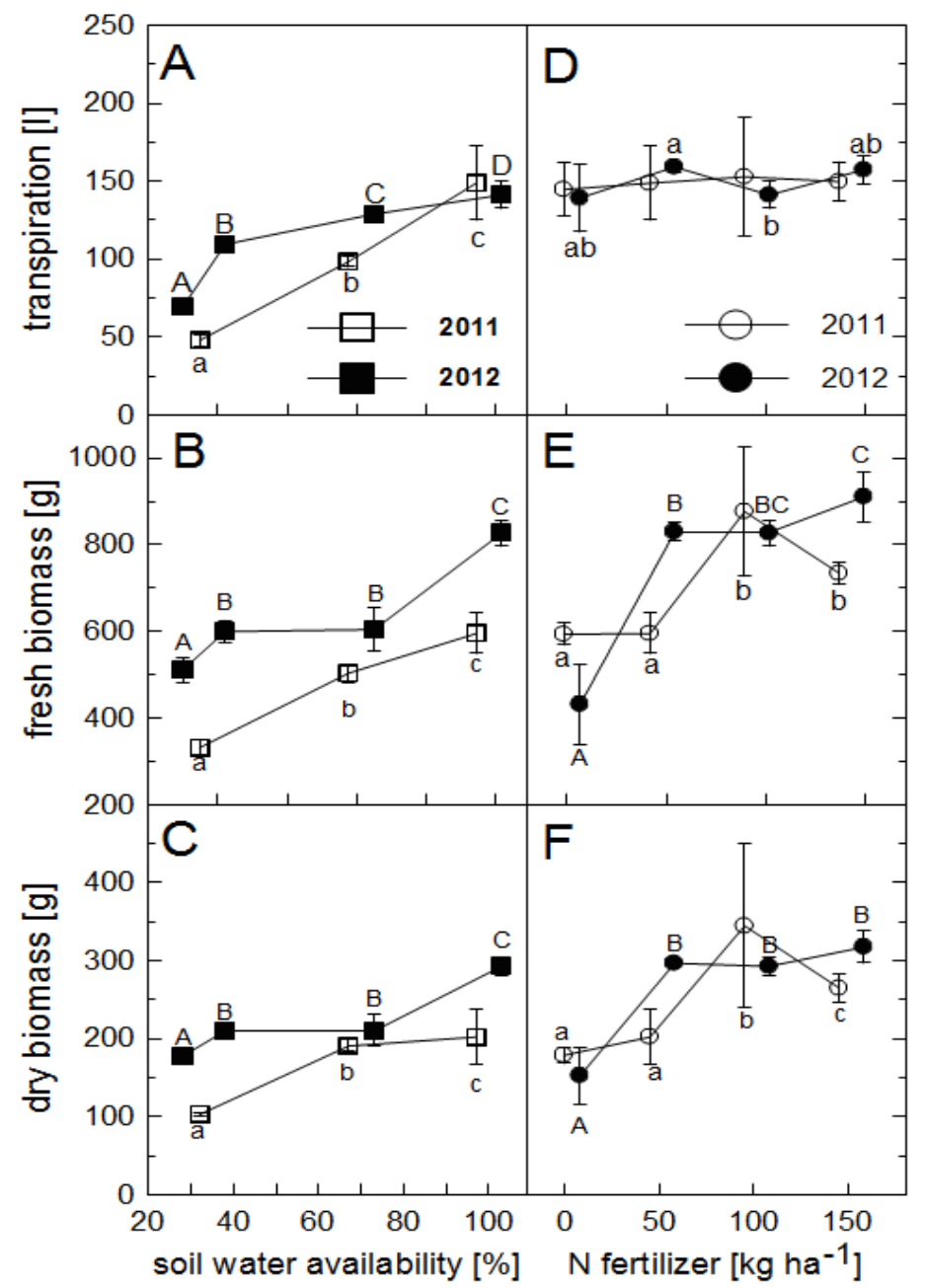

Fig. 2. Influence of the soil water content (nitrogen fertilization $50 \mathrm{~kg} \mathrm{ha}^{-1}$ ) (A-C) and nitrogen application (soil water availability 100\%) (D-F) on the cumulative transpiration, fresh biomass and dry biomass of Fallopia plants in the 2011 and 2012 experiments.
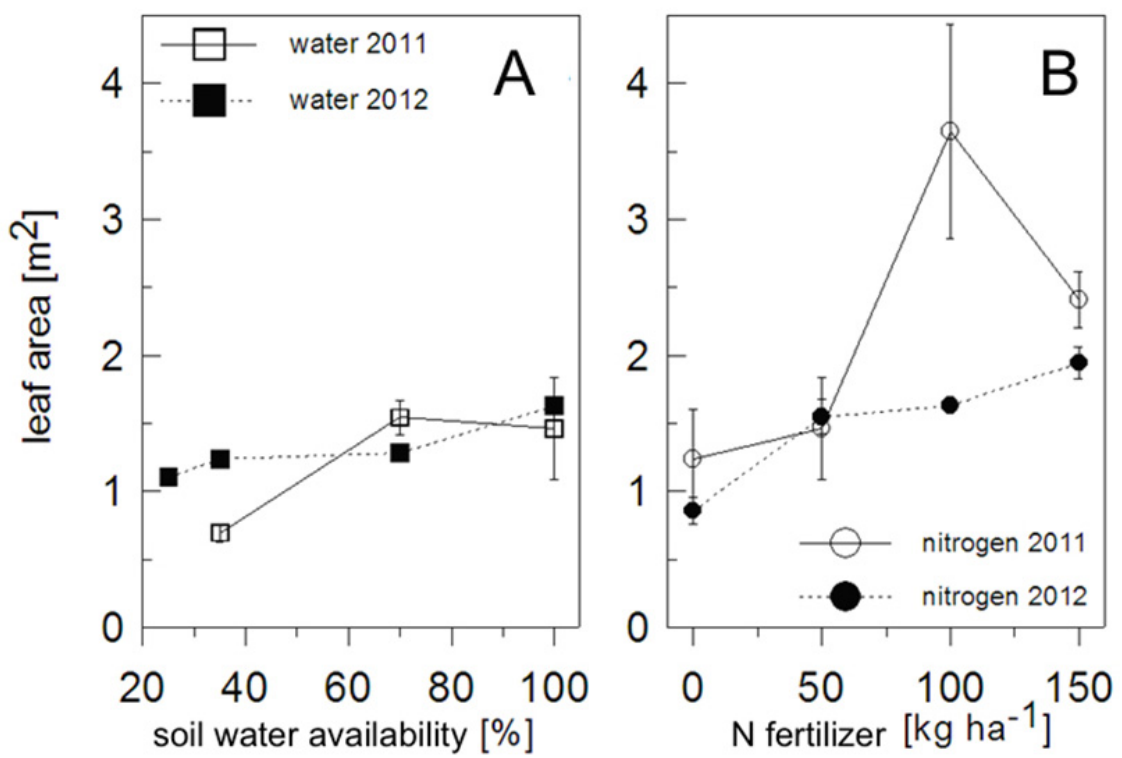

Fig. 3. Influence of the soil water content (nitrogen fertilization $50 \mathrm{~kg} \mathrm{~N} \mathrm{ha}^{-1}$ ) (A) and nitrogen application (soil water availability 100\%) (B) on the leaf area development of Fallopia plants in the 2011 and 2012 experiments. 
were no differences between the plant transpirations across the treatments (Fig. 2d). This is in contrast to 2012 in which a significant difference was found between the N 50 (141 l) and N 100 (159 1) treatments.

The consequences of the water constraints for both years in terms of aboveground biomass production are enlightened by the significant differences found between the treatments. For the watering experiment in the first vegetation period that was examined in 2011, the SWA 70 and SWA 35 biomass yields were 85 and $56 \%$ of the SWA 100 (596 g), respectively (Fig. $2 \mathrm{~b})$. The dry biomass followed the same trend with the SWA 70 and SWA 35 producing 94 and $50 \%$ of the SWA 100 , respectively (Fig. 2c). The nitrogen fertilization amount also shaped significant differences between the treatments in terms of primary production for both years (Fig. 2e and f). The Spearman's correlation between the aboveground fresh biomass and dry biomass with the $\mathrm{N}$ fertilization amount is significant at $0.528^{*}$ and $731^{* *}$, respectively. In 2011 the $\mathrm{N} 100$ yield was the highest with $876 \mathrm{~g}$, followed by a comparable amount for $\mathrm{N}$ 150 (734 g), while the N 50 and the N 0 had reduced yields of 596 and $594 \mathrm{~g}$ (Fig. 2e). In 2012 the N 150 took over the role of the best performer with a yield of $911 \mathrm{~g}$. The treatments N 100 and $\mathrm{N} 50$ followed with comparable productions of 827 and 830 g. The $\mathrm{N} 0$ reduced in yield to $431 \mathrm{~g}$. The same trend can also be recognized regarding the dry biomass production (Fig. $2 \mathrm{f}$ ).

The leaf area is less influenced by the soil water availability compared to the total biomass (Fig 3a). The increase of biomass in the second year is due to a higher stem growth. On the other hand, the nitrogen application increases the leaf area in both years (Fig. 3b). Soil water availability influencing also the leaf transpiration net $\mathrm{CO}_{2}$ uptake and transpiration of Fallopia (Fig. 4), even that the differences are not significant due to the high variability between the measured leaves on different plants. Thus stomatal reaction is triggered by the soil water availability and the VPD (Gollan et al., 1985). During the days with the lowest air to leaf water pressure deficit (ALVPD), the transpiration ranged from 3.9 and $5.4 \mathrm{mmol} \mathrm{m}^{-2} \mathrm{~s}^{-1}$, while the $\mathrm{CO}_{2}$ ranged from 7.5 to $9.7 \mu \mathrm{mol} \mathrm{m} \mathrm{m}^{-2}$ (Fig. 4a). Raising the ALVPD to $14.9 \mathrm{mPa} \mathrm{Pa}{ }^{-1}$, the transpiration for all the treatments increased to values of 8 and $10.6 \mathrm{mmol} \mathrm{m}^{-2} \mathrm{~s}^{-1}$, while the net $\mathrm{CO}_{2}$ exchange rates remained at the same level with mean values ranging from 7.6 to $9.1 \mu \mathrm{mol} \mathrm{m} \mathrm{m}^{-2} \mathrm{~s}^{-1}$. A clear response to the soil water limitation occurred when the ALVPD was $20.8 \mathrm{mPa} \mathrm{Pa}^{-1}$ and transpiration for the SWA 35 dropped to $6.3 \mathrm{mmol} \mathrm{m}^{-2} \mathrm{~s}^{-1}$, while the maximum for the SWA 100 was $8.6 \mathrm{mmol} \mathrm{m}^{-2} \mathrm{~s}^{-1}$ (Fig. 4c). Due to stomatal responses, the net $\mathrm{CO}_{2}$ exchange responded similarly to the water availability reduction with a minimum value for the SWA 35 of $6.1 \mu \mathrm{mol} \mathrm{m} \mathrm{m}^{-2}$ and maximum for SWA 100 of $7.9 \mu \mathrm{mol} \mathrm{m}^{-2} \mathrm{~s}^{-1}$. These measured relative high mean values for leaf transpiration $10.6 \mathrm{mmol} \mathrm{m}^{-2} \mathrm{~s}^{-1}$ in Fallopia are in line with various other crops like sunflowers (Helianthus annuus) and tomatoes (Lycopersicum esculentum), while the mean net photosynthesis is with $9.1 \mu \mathrm{mol} \mathrm{mmol} \mathrm{m}{ }^{-2} \mathrm{~s}^{-1}$ much lower than other productive crop species with a similar transpiration. The measured net $\mathrm{CO} 2$ exchange rates are $10-25 \mu \mathrm{mol} \mathrm{m} \mathrm{m}^{-2} \mathrm{~s}^{-1}$ for sunflowers, 12 $24 \mu \mathrm{mol} \mathrm{m} \mathrm{m}^{-2} \mathrm{~s}^{-1}$ for tomatoes and $18-26 \mu \mathrm{mol} \mathrm{m} \mathrm{m}^{-2} \mathrm{~s}^{-1}$ for eggplants (Solanum melongena) (Breckle et al., 2003). Also, Sida hermaphrodita, which is considered a highly productive bioenergy crop with heights up to 3-4 m, reaches net photosynthesis rates of 6 to $16 \mu \mathrm{mol} \mathrm{m} \mathrm{m}^{-2}$ in pot experiments (Veste et al., 2014), while Franzaring et al. (2014) reported values of $12-17 \mu \mathrm{mol} \mathrm{m} \mathrm{s}^{-1}$. In various experiments it could be shown that the net photosynthesis rates and the leaf conductance of annual

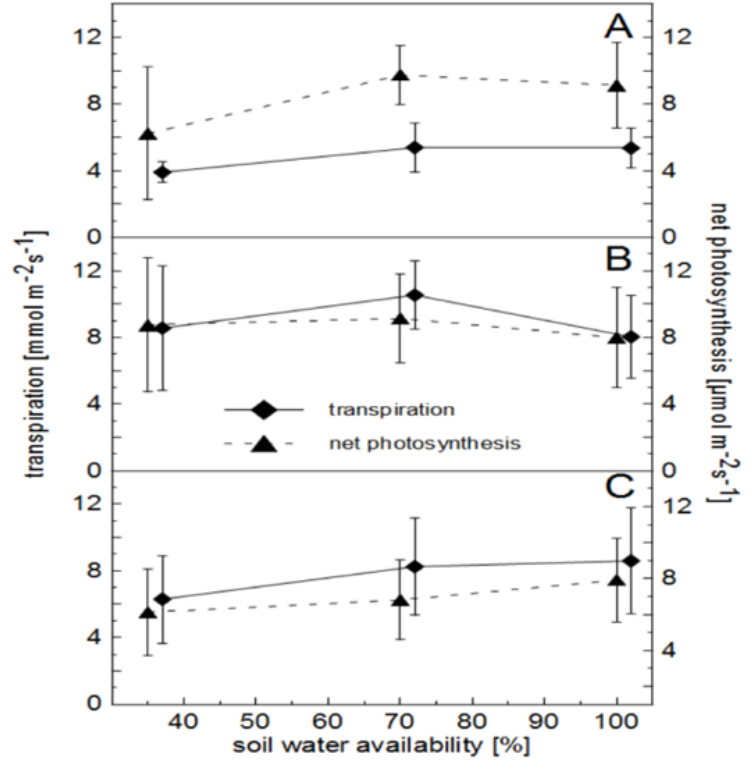

Fig. 4. Leaf transpiration and net photosynthesis in relation to soil water availability under various temperature conditions in the cuvette $\left(T_{\text {cuv) }}\right.$, air to leaf, water vapour deficits (ALVPD) and relative humidity regimes: (A) $T_{\text {cuv }}=20^{\circ} \mathrm{C}$; $\mathrm{ALVPD}=8.9 \mathrm{mPa} \mathrm{Pa}^{-1}$; $\mathrm{rH}=74 \%$, July $25^{\text {th }}, 2011$; (B) $T_{\text {cuv }}=25^{\circ} \mathrm{C} ;$ ALVPD $=14.9 \mathrm{mPa} \mathrm{Pa}^{-1}$; $\mathrm{rH}=53 \%$, June $29^{\text {th }}, 2011$; (C) $T_{\text {cuv }}=30^{\circ} \mathrm{C}$; ALVPD $=20.8 \mathrm{mPa} \mathrm{Pa}^{-1}$; $\mathrm{rH}=51 \%$, September $4^{\text {th }}, 2011$.

crops are higher than perennial crop species (Breckle et al., 2003).

To understand the implication of water constraints on the photosynthesis-stomata relation on the leaf level on the carbon balance and growth performance the complex interwind ecophysiological processes of the plants needs to be taken into account. In general, besides the direct effects leaf conductance on the $\mathrm{CO}_{2}$ uptake by diffusion, water limitation effects furthermore the mesophyll conductance and the lets to biochemical limitation of photosynthesis (Keenan et al., 2010). Stomatal limitation has also effects on the photorespiration and carbon loss can increase under drought stress (Long and Bernacchi, 2003; Veste and Kriebitzsch, 2013). This complex ecophysiological response resulting from stomatal and nonstomatal limitation of photosynthesis reduces the carbon gain of the plants. However, the net photosynthesis rates have only a small effect on plant growth and carbon allocation between the different organs. In most cases, the influence a water shortage has on the growth performance of a plant is more directly related to tissue formation than to a reduction in the provision of carbon assimilates during photosynthesis (Körner, 2013).

Therefore, on the plant level the transpiration-yield relation integrates the different ecophysiological and morphological responses to soil water availability. In our case, the aboveground fresh biomass and the cumulative transpiration were significantly correlated ( $\mathrm{rs}=0.704^{* *}$ ) (Fig. 5a). The relation is linear $\left(\mathrm{r}^{2}=0.94\right)$ with a calculated YWUE value of $4.79 \mathrm{~g} \mathrm{l}^{-1}$.

The correlation is significant between the aboveground dry biomass and the cumulative transpiration as well ( $\mathrm{rs}=0.631^{* *}$ ) with a linear relation $\left(r^{2}=0.94\right)$ (Fig. 5b). A linear relation between water use and biomass has previously been documented for various crops and climates under conditions of water deficiency (Ben-Gal and Shani, 2002a; Ben-Gal et al., 2003; Hanks, 1974). The WUE of Fallopia calculated from the 


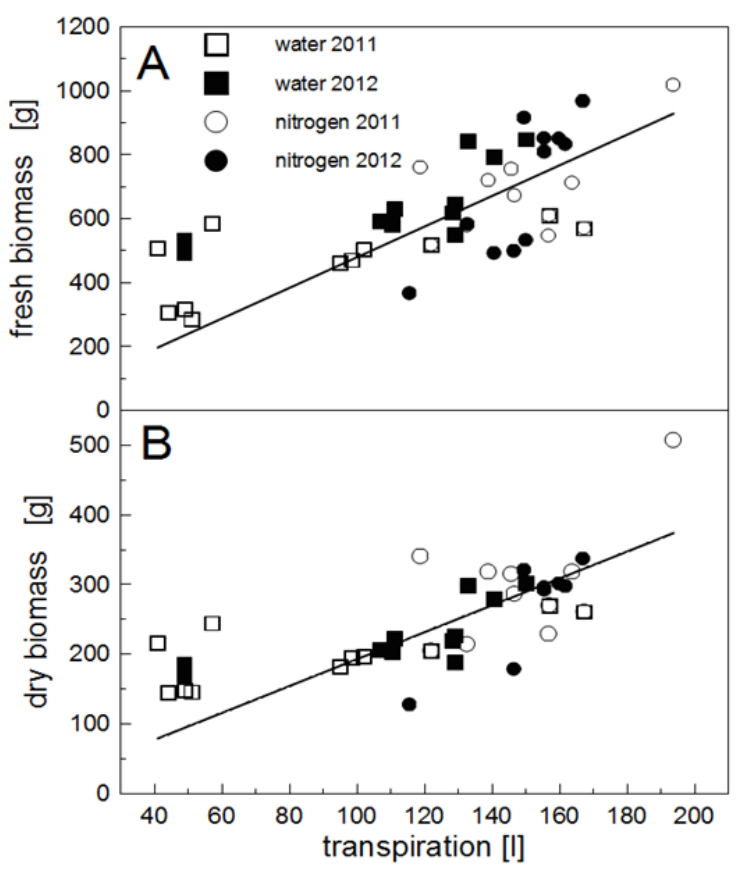

Fig. 5. Fresh biomass (A) and dry matter (B) yield as functions of Fallopia transpiration evaluated for all investigated plants. Yield and water uptake variations caused by irrigation and nitrogen fertilization during the experiments in 2011 and 2012. (A) YWUE: linear regression for all data $\left(\mathrm{y}=4.93 \mathrm{x}, \mathrm{R}^{2}=0.949\right)$. (B) WUE: linear regression for all data $\left(\mathrm{y}=1.92 \mathrm{x}, \mathrm{R}^{2}=0.94\right)$.

linear regression was $1.92 \mathrm{~g} \mathrm{l}^{-1}$ (Fig. 5b). In the literature there is not yet information about the WUE of Fallopia. However, our outcome is in line with a report from Clifton-Brown and Lewandowski (2000) for a Miscanthus pot experiment in which drought stress did not change the WUE. Being that Miscanthus is a grass species, its WUE ranged from 2.2 to $4.1 \mathrm{~g} \mathrm{l}^{-1}$ in a pot experiment and under field conditions between 2.64 and 4.83 $\mathrm{g}^{-1}$ (Cosentino et al., 2007). The calculated transpiration coefficient for Fallopia over all the applied treatments was 485.6 $1 \mathrm{~kg}^{-1}$ dry matter comparable to rye and barley with water consumptions of 400-500 L kg-1 (Ehlers, 1996, 1997; Larcher, 2003), while for maize 300-400 $1 \mathrm{~kg}^{-1}$, Miscanthus $3001 \mathrm{~kg}^{-1}$ (Lewandowski et al., 2009) and sunflowers 570-630 $1 \mathrm{~kg}^{-1}$ (Ehlers, 1996; Green and Read, 1983) are reported. However, in order to conclude that there is a generalized advantage of better water use efficiency by $\mathrm{C}_{4}$ plants under Central European climate conditions more detailed and comparable studies to cold-adapted $\mathrm{C}_{3}$ plants are needed. In that case, the physiological responses and adaptation of $\mathrm{C}_{4}$ plants to the Central European climate needs to be taken into account. In a long-term study, $\mathrm{C}_{4}$ plants (maize and sorghum) under optimal soil water conditions had an average of a $29 \%$ higher water use efficiency and under temporary drought stress a $50 \%$ higher water use efficiency compared to the investigated $C_{3}$ plants (fodder beet, sunflowers and Jerusalem artichoke) (Schittenhelm and Kruse, 2009). A recent study by Manderscheid et al. (2013) in northern Germany showed a particular maize cultivar to have a more efficient transpiration and water use than sorghum, because it was better adapted to the prevailing German weather conditions. To understand the drought tolerance of Fallopia in comparison to annual crops under field conditions, its deep rooting system needs to be taken into account. As a perennial plant the root and rhizome system is already established and able to mobilize reserves for plant growth in the spring and reach deep soil water tables. These features enable the plant to start growing even during drought periods in late spring and early summer which are not uncommon in East and North Germany, when maize is just starting to grow and is sensitive to drought conditions.

\section{CONCLUSION}

Our lysimeter experiment showed that the transpirationbiomass relation of Igniscum is comparable to rye and barley in terms of dry biomass production. Contrariwise, the water use efficiency calculated for leaf transpiration and net photosynthesis is lower compared to other crop species due to the relative low $\mathrm{CO}_{2}$ exchange rates. Despite the fact, that the calculated transpiration coefficient was higher compared to maize, which is mostly the reference for bioenergy crops, as a perennial plant IGNISCUM has various advantages under drought conditions compared to annual crops. The established deep rooting system and the rhizomes allow the plants to mobilize reserves for growth in the spring and to reach deeper soil water tables. This makes the plant more independent from the actual precipitation. These features enable the plant to start growing even during drought periods in late spring and early summer when maize is just starting to grow and is sensitive to drought conditions. These drought periods are not uncommon in eastern and northern Germany. From the viewpoint of the water use efficiency and growth performance, Fallopia has the potential to be used as a second generation bioenergy crop.

Acknowledgement. Thanks to Conpower Rohstoffe GmbH for providing the plant material and financial support of the study. Thanks to the two anonymous reviewer for valuable comments on the manuscript.

\section{REFERENCES}

Ben-Gal, A., Shani, U., 2002a. Yield, transpiration and growth of tomatoes under combined excess boron and salinity stress. Plant and Soil, 247, 211-221.

Ben-Gal, A., Shani, U., 2002b. A highly conductive drainage extension to control the lower boundary condition of lysimeters. Plant and Soil, 239, 9-17.

Ben-Gal, A., Karlberg L., Jansson, P.-E., Shani, U., 2003. Temporal robustness of linear relationships between production and transpiration. Plant and Soil, 251, 211-218.

Borkowska, H., Molas, R., 2012. Two extremely different crops, Salix and Sida, as a resource of renewable bioenergy. Biomass and Bioenergy, 36, 234-240.

Breckle, S.-W., Haverkamp, M., Scheffer, A., Veste, M., 2003. Ökologische Optimierung der Wassernutzung bei Bewässerung in ariden Gebieten. [Ecological optimization of the water use under irrigation in arid regions]. Bielefelder Ökologische Beiträge, 16, 1-110. (In German.)

Clifton-Brown, J.C., Lewandowski, I., 2000. Water use efficiency and biomass partitioning of three different Miscanthus genotypes with limited and unlimited water supply. Annals of Botany, 86, 191-200.

Cosentino, S.L., Patanè, C., Sanzone, E., Copani, V., Foti, S., 2007. Effects of soil water content and nitrogen supply on the productivity of Miscanthus giganteus Greef et Deu. in a Mediterranean environment. Industrial Crops and Products, $25,1,75-88$.

Ehlers, W., 1996. Wasser in Boden und Pflanze. Dynamik des Wasserhaushaltes als Grundlagen von Pflanzenwachstum und Ertrag. [Water in soil and plants. Dynamics of water 
balance as a basis for plant growth and yield]. Eugen Ulmer Verlag, Stuttgart. (In German.)

Ehlers, W., 1997. Zum Transpirationskoeffizienten von Kulturpflanzen unter Feldbedingungen. [About the transpiration coefficient of crop under field conditions]. Pflanzenbauwissenschaften, 1, 97-108. (In German.)

Franzaring, J., Schmid, I., Bäuerle, L., Gensheimer, G., Fangmeier, A., 2014. Investigations on plant functional traits, epidermal structures and the ecophysiology of the novel bioenergy species Sida hermaphrodita Rusby and Silphium perfoliatum L. Journal of Applied Botany and Food Quality, 87, 36-45.

Gerbens-Leenes, P.W., Hoekstra, A.Y., Van der Meer, Th., 2009. The water footprints of energy from biomass: A quantitative assessment and consequences of an increasing share of bioenergy in energy supply. Ecological Economics, 68, 3, $1052-1060$

Gollan, T., Turner, N.C., Schulze, E.-D., 1985. The responses of stomata and leaf gas exchange to vapour pressure deficits and soil water content. Oecologia, 65, 3, 356-362.

Gomez, L.D., Steele-King, C.G., McQueen-Mason, S.J., 2008. Sustainable liquid biofuels from biomass: the writing's on the walls. New Phytologist, 178, 3, 473-485.

Green, D.G., Read, W.L., 1983. Water use efficiency of corn, sunflower and wheat with limiting soil moisture. Canadian Journal of Plant Science, 163, 3, 747-749.

Hanks, R.J., 1974. Model for predicting plant yield as influenced by water use. Agronomy Journal, 66, 660-664.

Hanks, R.J., Rasmussen, V.P., 1982. Predicting crop production as related to plant water stress. Advances in Agronomy, 35, 193-215.

Havlík, P., Schneider, U. A., Schmid, E., Böttcher, H., Fritz, S., Skalský, R., Obersteiner, M., 2011. Global land-use implications of first and second generation biofuel targets. Energy Policy 39, 10, 5690-5702.

Ings, J., Mur, L.A., Robson, P.R., Bosch, M., 2013. Physiological and growth responses to water deficit in the bioenergy crop Miscanthus x giganteus. Frontiers in Plant Science, 4, 468.

Keenan, T., Sabate, S., Gracia, C. (2010). Soil water stress and coupled photosynthesis-conductance models: Bridging the gap between conflicting reports on the relative roles of stomatal, mesophyll conductance and biochemical limitations to photosynthesis. Agricultural and Forest Meteorology, 150, 443-453.

Körner, C., 2013. Growth controls photosynthesis - mostly. Nova Acta Leopoldina NF 114, Nr. 391, 273-283.

Larcher, W., 2003. Physiological plant ecology: ecophysiology and stress physiology of functional groups. Springer, Heidelberg, Berlin, New York.

Lazarovitch, N., Ben-Gal, A., Shani, U., 2006. An automated rotating lysimeter system for greenhouse evapotranspiration studies. Vadose Zone Journal, 5, 801-804.

Lebzien, S., Veste, M., Fechner, H., Koning, L., Mantovani, D., Freese, D., 2012. The Giant Knotweed (Fallopia sachalinensis var. Igniscum) as a new plant resource for biomass production for bioenergy. Geophysical Research Abstracts, 14, EGU2012-6060.

Lewandowski, I., Böhmel, C., Vetter, A., Hartmann, H. 2009. Landwirtschaftlich produzierte Lignocellulosepflanzen. [Agriculturally produced lignocellulose plants]. In: Kaltschmidt, M., Hartmann, H., Hofbauer, H. (Eds.): Energie aus Biomasse. Grundlagen, Techniken und Verfahren. [Principles, techniques and procedures]. Springer, Heidelberg, pp. 88-108. (In German.)
Lewandowski, I., Clifton-Brown, J.C., Scurlock, J.M.O., Huisman, W., 2000, Miscanthus: European experience with a novel energy crop. Biomass and Bioenergy, 19, 209-227.

Lewandowski, I., Heinz, A., 2003. Delayed harvest of miscanthus - influences on biomass quantity and quality and environmental impacts of energy production. European Journal of Agronomy, 19, 1, 45-63.

Long, S.P., Bernacchi, C.J., 2003. Gas exchange measurements, what can they tell us about the underlying limitations to photosynthesis? Procedures and sources of error. Journal of Experimental Botany, 54, 2393-2401.

Manderscheid, R., Erbs, M., Weigel, H.-J., 2013. Ecophysiological traits related to the growth response of maize and sorghum to drought and free air $\mathrm{CO}_{2}$ enrichment. Verhandlungen der Gesellschaft für Ökologie, 43, 23.

Mantovani, D., Freese, D., Veste, M., Hüttl, R.F., 2011. Modified wick lysimeters for critical water use efficiency evaluation and yield crop modelling. In: Proc. 14th Lysimeter Conference "Lysimeters in Climate Change Research and Water Resources Management", pp. 245-248.

Mantovani, D., Veste, M., Badorreck, A., Freese, D., 2013. Evaluation of fast growing tree transpiration under different soil moisture regimes using wicked lysimeters. iForest Journal of Biogeosciences and Forestry, 6, 190-200.

Midgley, G., Veste, M., von Willert, D.J., Davis, G.W., Steinberg, M., Powrie, L.W, 1997. Comparative field performance of three different gas exchange systems. Bothalia, $27,1,83-89$.

Naik, S.N., Goud, V.V., Rout, P.K., Dalai, A.K., 2010. Production of first and second generation biofuels: a comprehensive review. Renewable and Sustainable Energy Reviews, 14, 2, 578-597.

Phong, V.V.L., Kumar, P., Drewry, D.T., 2011. Implications for the Hydrologic Cycle Under Climate Change Due to the Expansion of Bioenergy Crops in the Midwestern United States. Proceedings of the National Academy of Science of the United States of America, 108, 15085-15090.

Pude, R., Franken, H., 2001. Reynoutria bohemica - eine Alternative zu Miscanthus x giganteus? Die Bodenkultur, 52, $1,19-27$.

Schittenhelm, S., Kruse, S., 2009. Wasserausnutzungseffizienz von Energiepflanzen. [Water use efficiency of energy crops]. 2. Symposium Energiepflanzen 2009. Gülzower Fachgespräche, 34, 108-118. (In German.)

Schwarz, K.-U., Greef, J.M., Schnug, E., 1995. Untersuchungen zur Etablierung und Biomassebildung von Miscanthus giganteus unter verschiedenen Umweltbedingungen. [Studies on the establishment and biomass production of Miscanthus giganteus under different environmental conditions]. Landbauforschung Sonderheft 155, 1-122. (In German.)

Seppälä, M., Antti, L., Jukka, R., 2013. Screening of novel plants for biogas production in northern conditions. Bioresource Technology, 139, 355-362.

Shani, U., Ben-Gal, A., Tripler, E., Dudley, L.M., 2007. Plant response to the soil environment: An analytical model integrating yield, water, soil type, and salinity. Water Resour. Res., 43, W08418, doi: 10.1029/2006WR005313.

Strašil, Z., Kára, J., 2010. Study of knotweed (Reynoutria) as possible phytomass resource for energy and industrial utilization. Research in Agricultural Engineering, 56, 3, 85-91.

Veste, M., Herppich, W., 1995. Diurnal and seasonal fluctuations in the atmospheric CO2 concentration and their influence on the photosynthesis of Populus tremula. Photosynthetica, 31, 3, 371-378. 
Veste, M., Kriebitzsch, W.-U., 2013. Einfluss von Trockenstress auf Photosynthese, Transpiration und Wachstum junger Robinien (Robinia pseudoacacia L.). [Effect of drought stress on photosynthesis, transpiration and growth of young black locust (Robinia pseudoacacia L.)]. Forstarchiv, 84, 35-42. (In German.)

Veste, M., Mantovani, D., Koning, L., Lebzien, S., Freese, D., 2011. Improving nutrient and water use efficiency of IGNISCUM - a new bioenergy crop. Jahrestagung der Deutschen Bodenkundlichen Gesellschaft 2011 "Böden verstehen - Böden nutzen - Böden fit machen", 3-9 September 2011, Berlin, Germany. Berichte der Deutschen Bodenkundlichen Gesellschaft. DBG, 4 p. Online http://eprints.dbges.de/739/
Veste, M., Quinkenstein, A., Freese, D., 2014. BioSida - Anbau von Sida als neue Kultur für Bioenergie und zur Inwertsetzung degradierter Standorte. [Cultivation of Sida as a new culture for bioenergy and valorisation of degraded sites]. Arbeitsgemeinschaft industrielle Forschung, Report, Cottbus, pp. 1-35. (In German.)

Vetter, A., Heiermann, M., Toews, T. (Eds.), 2009. Anbausysteme für Energiepflanzen. [Cropping systems for energy plants]. DLG Verlag Frankfurt/Main.

Weiland, P., 2010. Biogas production: current state and perspectives. Applied Microbiology and Biotechnology, 85, 849-860. (In German.)

Received 23 May 2014

Accepted 14 June 2014 